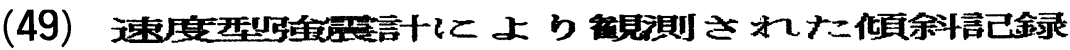

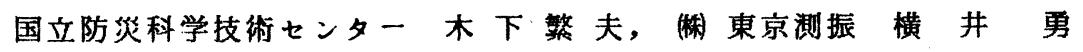

\section{§1. はじめに}

東京湾岸は我が国でも最も高い密度で速度型の強震計が配置されており、1987年12月17 日に発生した千葉県東方沖地震 $(M j m a=6.7)$ の祭、数多くの記録が同時に得られた。乙の地 震では小規模ながら東京湾岸では広域で液状化による噴砂現象を呈した。図一1は、干葉県 浦安市役所構内に設置された速度計の記録である。地震発生後20秒近くのところから

(因-1の矢印参照) $\mathrm{N}-\mathrm{S}$ 成分の零線が少し $\mathrm{N}$ 㑡に移動している現象がみられる。この原因 について、地震計が傾斜すると同様の現象が生ずることから、液状化に伴う側方流動との 関係について考察した。

尚、図ー 1 の記録は、噴砂地点から約 $300 \mathrm{~m}$ の地点で得られたものである。

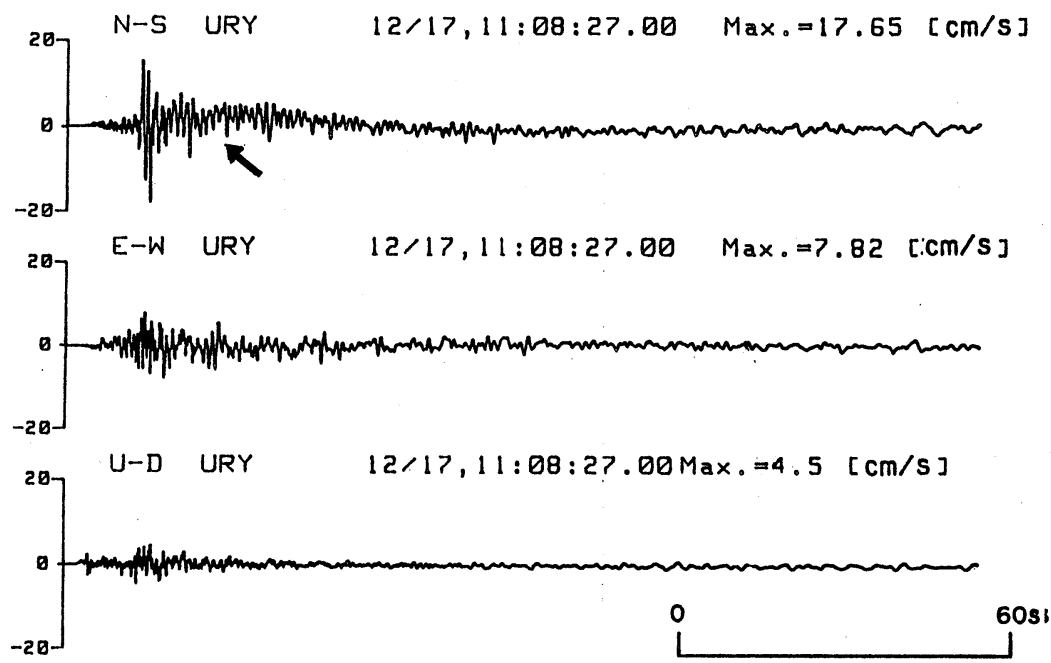

図-1＼cjkstart浦安市役所に打ける速度記録

\section{§2. 地震計と傾斜の関係}

強震計は従来加速度計が多用されているが、速度計，変位計もすべて計測原理は同一で、 基本的な構造に差異はない。いずれも地震の際に振子に作用する慣性力から振動の大きさ を計測している。振子の物理定数（固有振動数 $\mathrm{f} 。$, ダンピング定数 $\mathrm{h}$ ）を適当に選ぶてと により、図-2に示す如く加速度計，速度計，又は変位計となることは周知の通りである。 図-2から判る通り加速度計は高周波（短周期）㑡での感度が高いのに反し、低周波(長周 期) 側での感度が非常に低くなる性質をもっている。速度計は変位計と加速度計の中間で あり、長周期地震波の計測には加速度計よりも感度の点で有利である。又、近年速度波形 は、震度との相関が高いととや、P波 $\mathrm{S}$ 波の立上りが明瞭である等の理由から多用される ようになってきた。 
ところで、地震計を傾斜させると振子 (M)には、重力加速度 (g)が振子に作用し、あた かも地震が作用したと同様の信号発発生する。図-3の水平成分地震計では、傾斜角 $\theta$ の とき振子に作用する力はM·g $\sin \theta$ であるのに対し、図-4の上下成分地震計ではM·g $\cdot(1-$ $\cos \theta)$ となる。一般に $\theta$ が僅かの値であるので $\cos \theta=1$ となって上下動成分の地震計に はほとんど影響が出ないてとになる。

すなわち、地震計がわずかに傾斜した場合図一1の波形のように水平成分には傾動が 卓越し上下成分にはほとんどみられないものとなる。

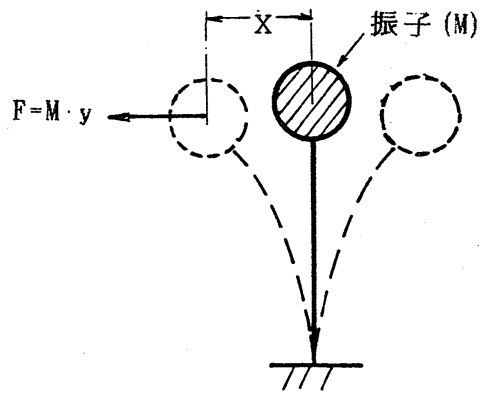

地動 $(\mathrm{y})$

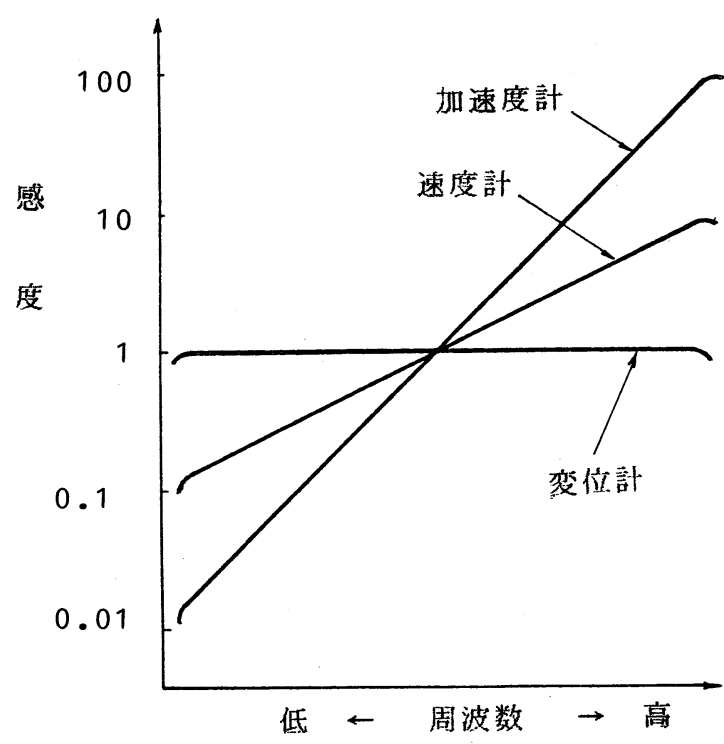

因-2 地震計の周波数特性

(変位計の感度虎一定とした場合)

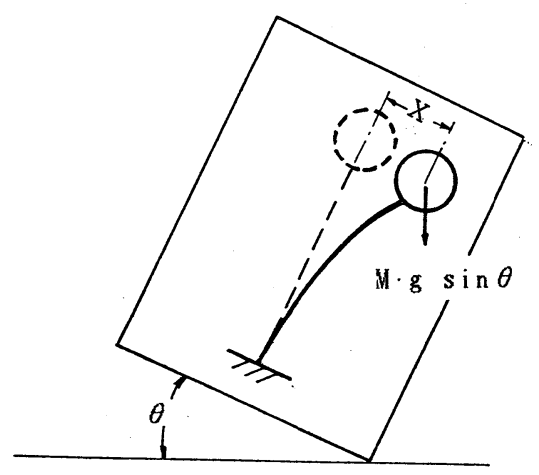

図-3 水平動地震計

傾斜による重力加速度の影響

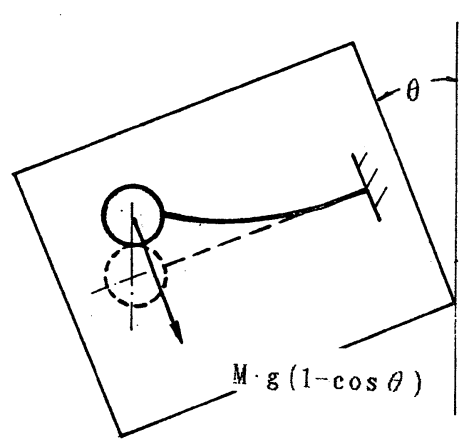

図-4 上下動地震計

傾斜による重力加速度の影響 


\section{§3. 傾斜角の推定}

実際に使用していると同じ計器を四-5のような振動台を利用した傾斜台にセットし、こ れを傾斜させた応答から伝達関数を確認し、シュミレーションから浦安市役所地点での傾斜 角を推定する方法をとった。図-6に㑯斜馀駼による応答波形を、図-7に実際の波形を 地震計の逆関数に通した場合の応答波形を示す。図-8は、図-1の記録から短周期成分应除

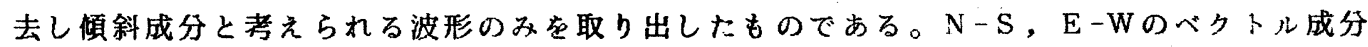
を考慮すると $20^{\circ}$ Wで最大となり、その傾斜角は 0.03 度となった。四一 9 は、データが得 られた強震計設置地点と噴砂現象の発生した地点であり、観測点から求めた傾斜方向 $N 20^{\circ}$ Wは、噴砂地域の方向と一致する。同様の現象は、江東区夢の島の速度計でも得られた。 ここでも傾斜角は南へ0.01度であった。

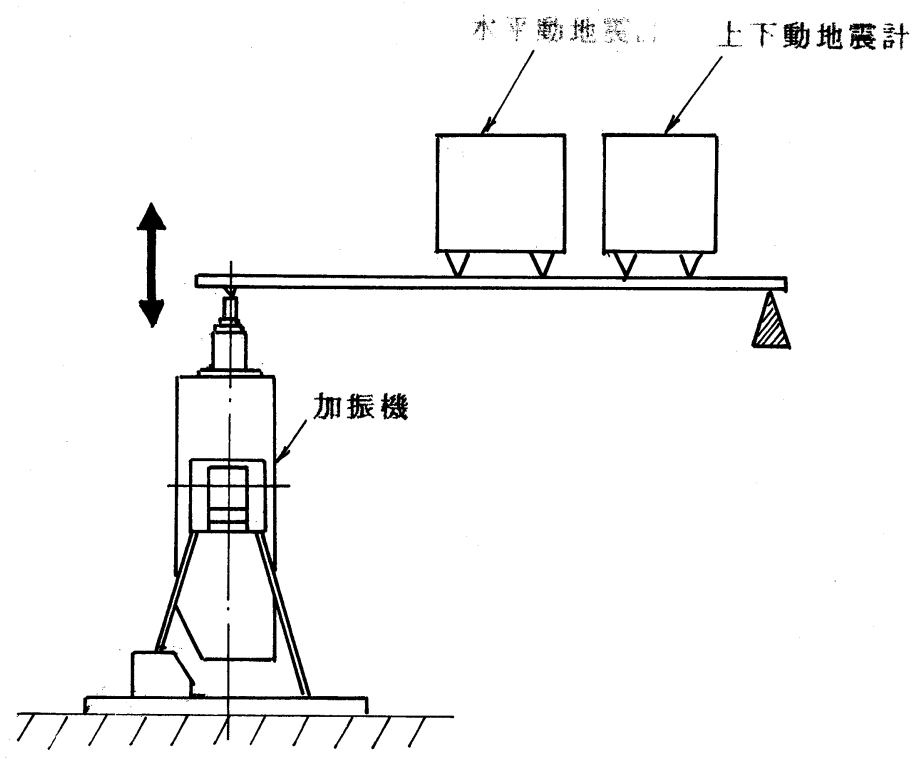

四-5 地震計の傾斜実験

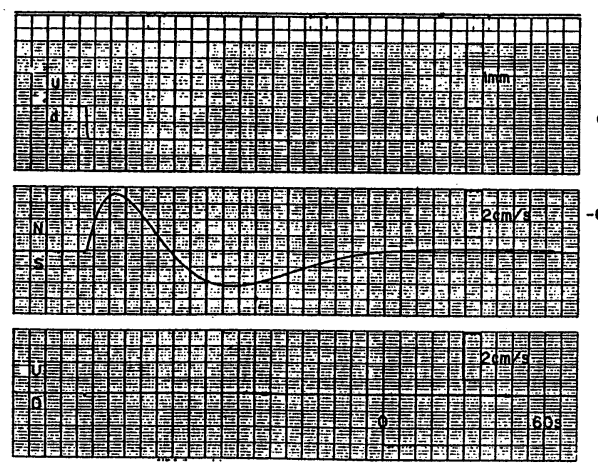

図-6 傾斜台試験の波形

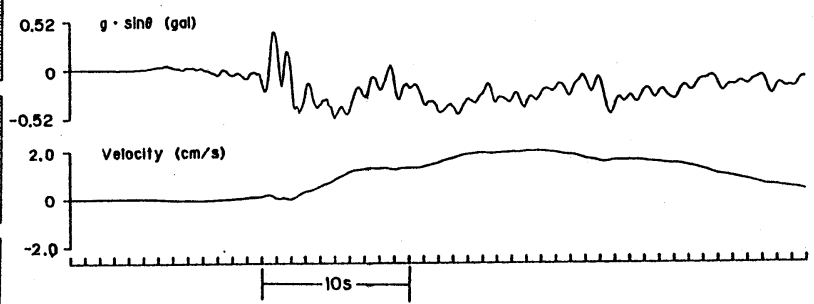

図-7シュミレーション波形 


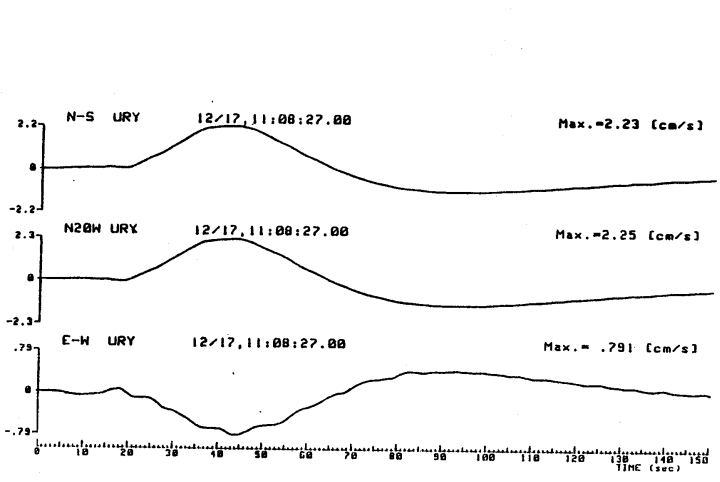

図-8 困-1の速度記録の傾斜成分

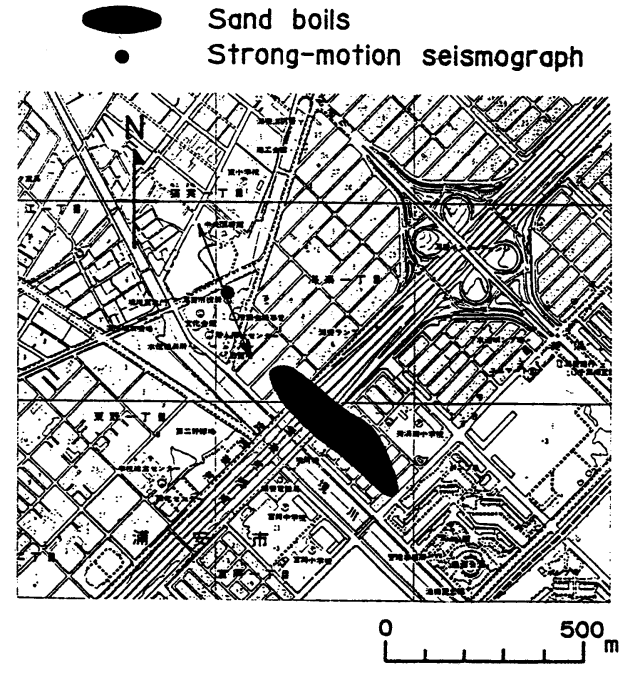

図-9 強震計設置地点と噴砂地域

§4. ま と め

地震動の際に想定される地表の傾斜角はでく僅かであり、非常にゆっくりとした現象と 考えられるので、従来の加速度計では感度の点で充分な信号が得られない。

てれに対して、加速度入力を基準とすると低周波数側で高い增幅率をもってる速度計 では今回のような明膫な傾斜記録が得られる。図-10は、図-1の記録を加速度波形に変換 したものである。傾斜による加速度值の変化は、高々0.2〜0.3galであり、この波形から 傾斜現象を直読できない。加速度波形では記録精度についても注意が必要である。

以上今回の傾斜記録からただちに液状化にともなう側方流動を断定できないが、可能性 も否定出来ないと考える。
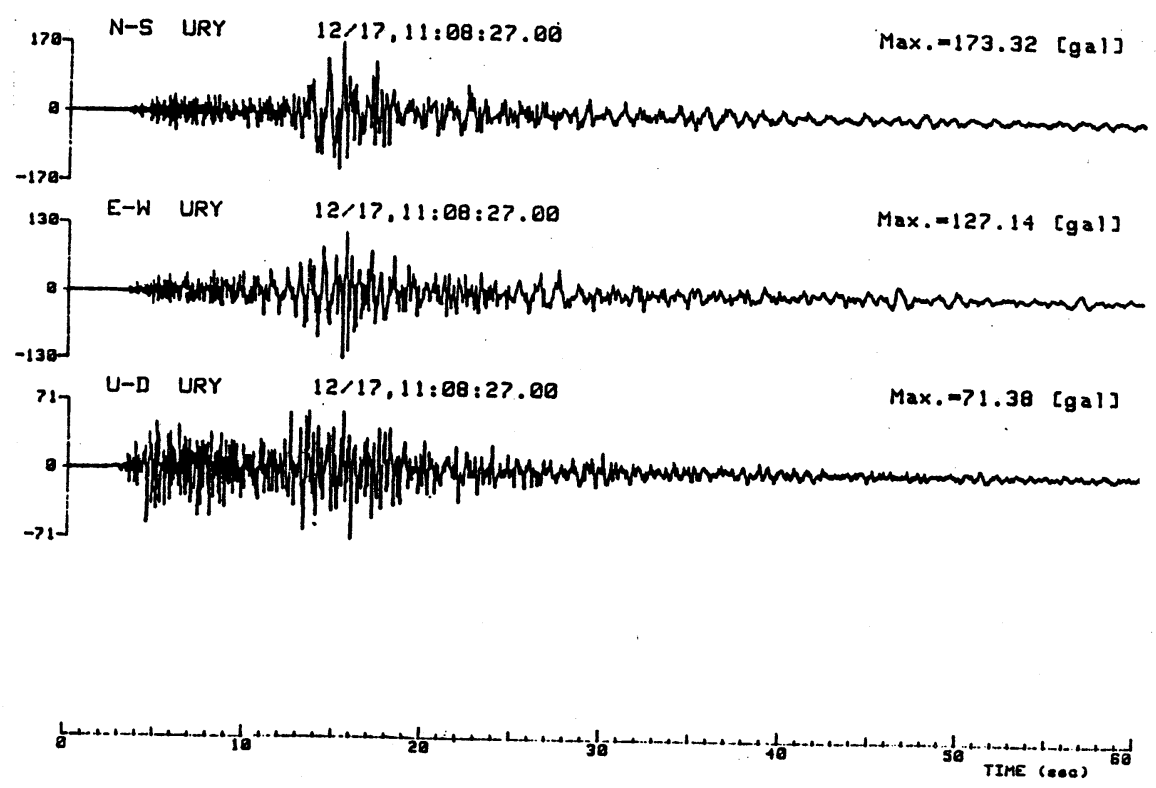

図-10 図-1の加速度波形 